\title{
A case study on women reducing drudgery through empowerment in agriculture in Dangs of Gujarat
}

\author{
G.J. BHIMANI AND C.S. DESAI
}

Received: 06.05.2015; Accepted: 21.05 .2015

See end of the paper for authors' affiliations G.J. BHIMANI

Krishi Vigyan Kendra (N.A.U.) NAVSARI (GUJARAT) INDIA
ABSTRACT : Despite rapid urbanization and improvements in social life, large numbers of poor women live in rural are as where modern technology is unavailable or unaffordable. Although technical innovation and adaptation are important, very many factors affect women's ability to benefit from technological change and these are often very location specific. Women will not benefit from hardware development unless this nexus of technical, institutional and socio-economic issues is addressed. With the help of Government Agencies, NGOs, Krishi Vigyan Kendra the women of the Dang are started various activities like small scale processing or small scale industries, group level farming to increase production. In the Dang's there are large number of SHGs exists and carried out activity to improve socio-economical status of society. Gujarat tourism department facilitates readily available market by increasing numbers of tourists who never come across such kind of things will buy producers price. The Dang's is emerging as a role model for women empowerment through agriculture and also drudgery reducer for society hence called Leader.

KEY WORDS: Women empowerment, Drudgery reduction, Women in agriculture

- HOW TO CITE THIS PAPER : Bhimani, G.J. and Desai, C.S. (2015). A case study on women reducing drudgery through empowerment in agriculture in Dangs of Gujarat. Asian J. Home Sci., 10 (1) : 235-239. 